\title{
THE WRITER'S WEBSITE AS A MULTIMEDIA RESOURCE FOR STUDYING THE HISTORY OF CONTEMPORARY RUSSIAN LITERATURE
}

\author{
Margarita Gudova ${ }^{1 *}$, Valeri Gudov ${ }^{2}$ \\ ${ }^{1}$ Prof. Dr., Ural Federal University, Yekaterinburg, RUSSIA, email: M.J.Gudova@urfu.ru \\ ${ }^{2}$ Ass. Prof, Ural Federal University, Yekaterinburg, RUSSIA, email: V.A.Gudov@urfu.ru \\ ${ }^{*}$ Corresponding author
}

\begin{abstract}
The authors of the article consider the concept of multimodal pedagogical design in the works of the founders of this concept M. Kalantzis and B. Cope. They connect the necessity of multimodal pedagogical design implementation with the formation of new, non-didactic digital pedagogy and the need to strengthen the emotional involvement of students, especially those from another culture and need to be immersed in a socio-cultural context. The experience of applying multimodal pedagogical design is analysed on the example of using the website of Russian writer and public figure Zakhar Prilepin, who is developing his blog, collecting critical and analytical materials, materials for the writer's creative biography. The discussion about writer's website as one of the tools of multimodal pedagogical design is organized with participation of researchers from the Ural Federal University, Ural State Pedagogical University, and foreign colleagues. In conclusion, it is concluded that only by engaging modern multimodal means of knowledge transfer, such as writer's websites, blogs, can we successfully attract and retain the attention of the audience in the process of remote learning.
\end{abstract}

Keywords: emotionality, engagement, history of contemporary Russian literature, multimodality, multimedia resource, pedagogical design, post-literacy, writer's website

\section{INTRODUCTION}

In today's world, the problem of updating the education system and those principles of organizing pedagogical relations that were used in the Humboldt system of education is acute. The most radical change, which becomes possible with the development of information and computer technologies, is the abandonment of traditional didactics and the transition to multimodal pedagogical design.

Multimodal pedagogical design is becoming an increasingly hot topic in digital pedagogy. The first article that opened this topic to the global educational community was written by prominent educators, founders of the Learning by Design research group Mary Kalantzis and Bill Cope in 2003 as a manifesto of this scientific and pedagogical community, and since then this topic has been attracting increasing attention from educational scientists, aestheticians, designers, and programmers around the world [Kalantzis, Cope, 2004].

Although the transition to digital educational technologies and remote learning has led to the fact that within 
the Russian scientific and pedagogical international community people are increasingly talking about the revolution in education, B. Cope and M. Kalantzis state that "the paradox is that information technology itself does not mean a revolution in education, it allows repeating and testing old didactic methods, and moving to a new quality of education, personalized, inspiring and friendly" [Cope, Kalantzis, 2021, 1].

\section{METHODOLOGY}

In discussing the problems of multimodal pedagogical design, we will follow the methodological guidelines of the new digital pedagogy defined by Bill Cope and Mary Kalantzis in their joint book New Learning: Elements of a Science of Education (2012) as well as in the articles on pedagogical design, video lectures, and polemical notes by these scholars and their students.

Pedagogical design is understood by B. Cope and M. Kalantzis as development of an order of pedagogical procedures resulting in knowledge movement/addition as well as selection of optimal models for knowledge movement in various academic and sociocultural spheres: such as selection of activity types, determination of activity sequence, transition from one activity to another, and determination of results of this activity [Kalantzis, Cope, 2010, 210].

The need for pedagogical design, according to these scholars, stems from the needs of that coming digital world. To prepare people for life in this coming digital society with a digital economy, according to B. Cope and M. Kalantzis, a new digital educational environment is required. The new (digital, virtual, or blended) educational environment, on the one hand, "may be more relevant to a changing world, more appropriate to meet societal expectations, and more effective in managing educational resources," and on the other hand, will more fully address the communicative characteristics of first generations born and raised in the mobile Internet and smartphone era, and consequently will "more fully meet the needs of students increasingly immersed in digital and globalized lifestyles, from the sources of entertainment they choose to how they work and learn" [Kalantzis, Cope, 2012, 200].

The radical difference between the understanding of pedagogical design in traditional classroom-based, classroom-lesson-based learning and in remote online learning based on information and computer technologies is based on B. Cope and M. Kalantzis' multimodal understanding of the new literacy of the 21 st century in the books and articles by G. Kress and T. van Leeuwen. These scholars substantiated that with the emergence of new digital media there is a need to form a new integrated literacy in relation to texts of new types [Van Leeuwen, Kress, 2009] - audio, video, game 3D, augmented and virtual reality, film reality. M. Kalantzis and B. Cope call complex literacy in relation to texts of different nature as multiliteracy [Cope, Kalantzis, 2016], their closest colleague in the New London Group G. Kress called multimodal literacy [Van Leeuwen, Kress, 2009], and we use the term "post-literacy", it was developed by us in extensive research 2010-2015 [Gudova, 2011]. Accordingly, following this methodology, we hypothesize that in order to form a new literacy, such as multiliteracy, or multimodal literacy, or post-literacy it is necessary to use pedagogical design that includes a large variety of media - in digital, interactive screen pedagogical interaction can more actively use such multimedia resources of social networks as writers' blogs that include files with books and movies, video recordings, audio materials, augmented reality elements, and so on. In remote learning the need for multimodal pedagogical design and appeal to social networks and blogs of modern writers is determined not only by the software, basic didactic units, but also by the need to interest, involve participants in the educational process, keep them at the screens of computers and smartphones, and for this "to fully engage the sensitivity and emotionality of students and trainers" $[2,18]$.

\section{RESULTS}

We decided to test the hypothesis that in modern digital pedagogy it is necessary to use multimodal pedagogical design, involving the maximum possible variety of information sources on the studied topic. In our case we recognise the example of the topic "Russian existential philosophy in literature and cinema" for students from China, studying in Ural Federal University in a remote, digital format since the winter semester 2019/2020 academic year.

When teaching students from another culture, it is especially important to make it so that at the same time there was an immersion in a new for them Russian and European cultural context, familiarity with literary primary sources, living the state of intra- and extra-inhabitation with the reality of artistic existential works, and mastering the necessary historical and cultural material, basic provisions of existentialist philosophy, familiarity with additional research literature.

In the traditional didactic system, all these tasks would be solved while reading verbal texts of literary, philosophical and commentary sources. That is, within the limits of addressing texts of one modality. 
In the methodology of multimodal pedagogical design, we must supplement the study of verbal texts with texts of other and more complex modalities. In our opinion, it is possible to solve the problems of multimodal pedagogical design most fully: using the familiar to students electronic environment of social networks, emotional involvement in the material under study, immersion in the cultural context, in the process of using such a multimedia educational resource as a writer's blog.

Blogs of modern writers in modern social networks, such as YouTube, Instagram, Facebook, refer to the New Media by their information and communication features. New digital media have become not only a space for publishing literary works created in the traditional way, that is, the digitization of creativity, but also a space for direct communication between the writer and his or her recipients - readers, researchers, commentators. Writer's blogs in social networks are a strong way of immediate presentation of the author's text to the public and an immediate response to every publication, whenever it occurs. In addition, modern media have provided writers not only with an open platform for public expression, but also with systems for searching and storing documentation, creating a public diary and a personal archive of all documentation related to a writer's life and work. This gives students the opportunity to penetrate the creative kitchen of the writer, free post-literacy uses of multimedia resources processing, storage, and translation of information in the process of obtaining new knowledge about contemporary Russian literature. The degree of virtual social communicativeness has become largely determined by the interest in the work of the writer, his popularity among the reading audience, including the student audience.

Similar changes have taken place in the field of literature, which is isomorphic to the field of art in general. The position of each individual writer has now become defined by a large list of parameters that configure the very different lines of professional creative activity of the intellectual that each writer is. The blogs of modern writers show that the notions of "cultural policy" and "state order" have returned to the life of modern Russian artist, each of which determines the further substantial trajectory of the development of the writer's creativity.

At the same time, the conditions of existence and the sociocultural practices in which this or that artist is included in the process of his or her creative work, and the ways of articulation through which the artist speaks of his or her practices, are changing in each writer's life. Today, artists living in the new conditions of the art field, forced to present concepts and / or programs of their works, to explain and justify their own actions and personal life events, are themselves engaged in the creation of narratives about themselves (literary, musical, visual), collecting various forms of documentation of their creative life, as well as the creation of websites, online diaries - blogs, online groups and other media platforms for representation and promotion of their work. Contemporary art has thus made a few more steps in the direction of autonomous existence toward heteronomous one.

Zakhar Prilepin stands apart in the field of contemporary art, but at the same time, in many ways he continues the tradition of Russian art of past years. Zakhar Prilepin plays on several sites within the field of literature: it is a site of literary creativity - he is the author of world famous and translated novels, novellas, and stories, it is a site of literary study - he is the author of three studies in the history of Russian literature: A Fellow of the era: Leonid Leonov. A Study - 2010, Marienhof, Kornilov, Lugovskoy: Different Poets - 2015, Platoon: Officers and Militiamen of Russian Literature - 2016, it is a section of author song - he is the author of several song albums, and it is a section of the blogosphere - he is the author of several online diaries - on LiveJournal, VK.com, You Tube, Instagram, Twitter. All this makes the figure of Z. Prilepin noticeable and recognizable in the field of modern Russian literature, and on the other hand, open and contradictory.

Zakhar Prilepin has been keeping his network diary tirelessly from 2007 to the present day. "This journal was created at Zakhar's request, so that he would be able to comment on certain blog posts on livejournal.com without being anonymous. In the near future there will be no entries here on behalf of the writer. But comments are written by him, and only by him" [prilepin.livejournal.com, 2007]. Such a declaration as the first entry clearly indicates that its author had a poor idea of what an online diary is, how it is kept, and why it is needed. Prilepin opened it to comment on the statements of others or even to remain silent, but gradually the blog became what it is today - a way of documenting life. At first, posts were made rarely - no more than once a month: March 7, April 24, June 20, July 16, August 23, August 29, October 19 and 31, November 28, in December - 10,12, 17, and 25. Gradually the diary gained momentum. It began to publish reflections on events in the writer's mental life and the publicist's reflections on events and processes in the life of the country. On the pages of the diary began to collect his speeches in newspapers, on YouTube, on television, on the radio, the covers of the published books, magazines with publications of his works, congratulations to his friends, hymns to the Russian woman, the diary of his life is a movement of his thoughts and feelings, reactions and impressions, his agreement, and his protest. The analysis of this diary is the task of the 
psychoanalyst. We can record that in these texts Prilepin reveals himself as a master, a connoisseur and lover of words and images, as a collector of others' figurative and vivid statements, verbal and musical, poetic, and cinematic. That is, above all, an artist, not a political or media character.

The official website of Zakhar Prilepin includes several sections: News (this section duplicates the entries in the LiveJournal), Help for Donbass, Bibliography, Reviews, Media, Shop, Contacts. In the section "Bibliography" you can find links to all publications of literary works by Zakhar Prilepin, which were published in different countries in book or magazine editions and publishers. The MP3 and video options allow you to access recordings of musical and cinematic works. The "Shop" section offers, in addition to buying books or discs, an "author's clothing line" of the "I came from Russia" series, including 2 items of clothing: a vatnik and a T-shirt. The option "Helping Donbass" takes the reader to the website of the Zakhar Prilepin Charitable Foundation, where all the details are listed, as well as reports on received transfers and money spent - a total of 56 reports over four years, starting in 2014. The "Contacts" section includes both links to the writer's social networks and online diaries and addresses of his literary agent in Russia and abroad, the public relations manager and manager of $Z$. Prilepin's musical and theatrical performances, as well as the curator of the writer's official website.

And here Zakhar Prilepin appears not only as a wordsmith and public figure, but as a public charitable institution, which brings the scale of his activities to a fundamentally different level. It translates his words and pain into public social action, for which he gives a public account. The "Media" option opens a diverse world of photo-video-audio documents, revealing the secrets of the author's self-telling books, poems, music, clothes about himself. The photographs tell us about his parental family, home, childhood, family, spouse, and children of Zakhar himself grown up, finally about his life path - the army-military from Chechnya to Donbass, about his literary path - from Nizhny Novgorod University to book fairs and literary awards and presentations in different parts of the world, about his family path, including marriage and summer holidays with children. The video collection includes interviews with Zakhar Prilepin as well as recordings of his talk shows and programs, numerous press conferences, speeches, documentaries, book titles, trailers for films featuring him, friendly gatherings, theatre performances, news clips, and music videos. All this characterizes Zakhar Prilepin as a well-organized "media persona", a persona about whom old and new media writes, talk and show, and a persona who organizes and creates content for a variety of media.

The reviews section presents us with a writer "whose talent overcomes his convictions" [zaharprilepin.ru], as one critic asserts, but in this section, we find critical works, scholarly works, bloggers' entries, and "Poems to Zakhar", where an exclusively positive assessment of Zakhar Prilepin's s life and work is given in various forms, including poetry. Notes, scholarly and journalistic, with other content should not be found on this site.

Finally, the biography of Zakhar Prilepin, made in a separate information section looks the most formalized and concise, containing information about the time and place of birth, parents, place of residence, education, publications, books, anthologies and collections compiled by him, about Prilepin's filmography as an actor, musician's discography, writer's literary prizes, literary and musical, cinematographic leanings, activity is characterized as journalism, beliefs - national Bolshevism, marital status - happily married, achievements four children. And nothing is said about his military or political activities.

Having analysed Zakhar Prilepin's website, we see that indeed the profession of the writer is the least codified, and that each artist constructs his own image as a creator whose work is diverse and penetrates different areas of everyday life. The right to create in literature, music and film, the artist Prilepin brings into everyday life and creates his private world and the world of his public activity. He also appropriates the right to create not only the artistic picture of the world, but also the political map of the world, showing himself as an influential media persona and as a social activist, whose work is aimed at rearranging an imperfectly arranged existence. Zakhar Prilepin in his work is an inseparable trinity of writer-activist-mediator, a man who creates his world, explains it, protects it, and promotes it to others in the open virtual public space.

\section{DISCUSSION}

By analysing the work of Z. Prilepin we have shown which existential problems embodied in the artistic narratives of novels, novellas, literary biographies, film scripts we can explore together with students. This co-production of knowledge about existential philosophy and existential problems of modern man is also one of the most important principles of the new digital pedagogy when knowledge is not presented by a teacher but is produced in the joint cognitive, research activity of researchers-scientists and researchers-students.

The use of writer's blog texts in multimodal pedagogical design finds different assessments in the scientific and pedagogical community today. Thus, T.I. Alieva and G.V. Uradovskikh argue that modern resources of media, Internet, movies, computer games and music, allow creating a variety of educational environments, 
moving from one to another person will receive continuing education, where formal and non-formal educational processes will complement each other, forming a consolidated result in the form of new integrated literacy [Alieva, Uradovskikh, 2016, 379-380]. N.A. Simbirtseva considers the involvement of visual, media and multimedia texts in multimodal pedagogical design as one of the factors of critical thinking education, which is essential in relation to the visual information dominating in the modern world, a reliable way to develop the skill of reading a visual text competently [Simbirtseva, 2020,66]. Such scholars as Rafael Fortesa F.F. argue that audio-visual design of the material studied in educational classes always bears the signs of a certain ideology, and forms not only the body of knowledge on the studied discipline, but also ideological attitudes and system of values transmitted explicitly, so the selection of such materials, must be very careful and meaningful [Fernandez, R. F. F., Rubtsova, E. V., \& Rojas, S. A. F. 2021, 172].

\section{CONCLUSION}

Thus, having analysed 1) the theory of multimodal pedagogical design in the founders of this direction of development of pedagogical thought M. Kalantzis and B. Cope, 2) our own experience in multimodal pedagogical design of the website of the writer Zakhar Prilepin with articles and reflections of critics, books and scripts, 3) research of other scholars of education about the effectiveness of using websites and blogs of writers as an educational resource in the pedagogical design of e- learning processes, when homework and practical work should interest, engage, evoke an emotional response, we conclude that the tools of pedagogical design are not only the most effective, but also the most important ones. Traditional forms of reading books, listening to lectures, doing written work, writing essays, must be combined with new forms made possible by the digital format of homework and screen meetings with the teacher, the possibility to show not only slides with presentations, but also to watch and discuss videos from YouTube or other necessary resources in social networks. Combining educational platforms with the familiar to learners' social networks, where they are used to watch movies, listen to music, read books, learn languages, creates a positive emotional background for students, motivates them to collaborative productive cognitive work, allows teachers to successfully solve difficult pedagogical problems in the conditions of remote digital interaction and multimodal pedagogical design.

\section{REFERENCE LIST}

Alieva T.I., Uradovskih G.V. 2016. Variativnye obrazovatel'nye sredy - zapros segodnyashnego dnya // Vospitanie i obuchenie detej mladshego vozrasta. [Variative educational environments - the request of today // Upbringing and education of young children]. 5. (in Russian)

Cope B., Kalantzis M. 2006. A Pedagogy of Multiliteracies: Learning by Design, Palgrave.

Cope B., Kalantzis M. 2021. The Changing Dynamics of On-Line Education: Five Theses on the Future of Learning // Foreign Language Learning in The Digital Age: Theory and Pedagogy of Developing Literacy. Ed.by C. Lutge. London: Routledge,

Cope B., Kalantzis M., D. Searsmith. 2020.Artificial Intelligence for Education: Knowledge and it's Assessment in Al-enable learning ecologies // Educational Philosophy and Theory. London: Routledge

Fernandez, R. F. F., Rubtsova, E. V., \& Rojas, S. A. F. 2021. Content Edulcoration as Ideology Visualization in an English Language Coursebook. Praxema. 4

Gudova M.YU. 2011. Postgramotnost' kak aktual'naya problema sovremennoj kul'tury // Obrazovanie i nauka. Izvestiya UrO RAO. [Post-literacy as an urgent problem of modern culture // Education and Science. Proceedings of the UrO RAO]. 9 (88). (in Russian)

Kalantzis M., Cope B. 2010.The Teacher as Designer: Pedagogy in the New Media Age. // E-Learning and Digital Media. 7 (3).

Kalantzis M., Cope B. 2012. New Learning: Elements of a Science of Education, Cambridge University Press

Kalantzis M., Cope B. 2004. Designs for Learning // E-Learning. 1 (1).

Prilepin Z. (2007). Zhivoj zhurnal. [LiveJournal] URL: https://prilepin.livejournal.com/2007/03/07/ (The data of this article was collected on 19.04.2018) 
Prilepin Z. Oficial'nyj sajt. [Official site]. URL: zaharprilepin.ru/ru/otzyvy (The data of this article was collected on 19.04.2018)

Simbirceva N.A. 2020. Opyt razvitiya kriticheskogo myshleniya skvoz' prizmu vospriyatiya vizual'nogo teksta: psihologo-pedagogicheskij aspekt // Izvestiya Ural'skogo federal'nogo universiteta. Seriya 1: Problemy obrazovaniya, nauki i kul'tury. [Experience in the development of critical thinking through the prism of visual text perception: the psychological and pedagogical aspect // Proceedings of the Ural Federal University. Series 1: Problems of Education, Science and Culture]. 4 (201). (in Russian)

Van Leeuwen, T., Kress, G. 2009. Multiliteracies in Motion: Current Theory and Practice. Edited by David R. Cole, Darren Lee Pullen. NY: Routledge. 